\title{
Unity, OBJectivity, AND The PASsivity OF EXPERIENCE
}

\author{
Anil Gomes \\ Trinity College, University of Oxford \\ Forthcoming, European Journal of Philosophy [accepted 2016]
}

In the section 'Unity and Objectivity' of The Bounds of Sense, P.F. Strawson argues for the thesis that unity of consciousness requires experience of an objective world. My aim in this essay is to evaluate this claim. In the first and second parts of the essay, I explicate Strawson's thesis, reconstruct his argument, and identify the point at which the argument fails. Strawson's discussion nevertheless raises an important question: are there ways in which we must think of our experiences if we are to self-ascribe them? In the third part of the essay, I use Kant's remarks concerning the passivity of experience to suggest one answer to this question: in self-ascribing experiences, we must think of them as passive to their objects. This can be used to provide an alternative route from unity to objectivity.

\section{Introduction}

P.F. Strawson's take on Kant's transcendental deduction of the categories in The Bounds of Sense contains stretches of argument as dense, difficult, and downright puzzling as anything to be found in Kant. My concern in this essay is the section 'Unity and Objectivity', in which Strawson argues 
that 'for a series of diverse experiences to belong to a single consciousness it is necessary that they should be so connected as to constitute a temporally extended experience of a unified objective world' (1966, p. 97). More prosaically: that unity of consciousness requires experience of an objective world.

This is a striking claim. If true, it would show the unavailability of a perennially tempting thought: that one could have all of this sensory experience in the absence of any objects in the world. Strawson's claim is everything that a philosophical thesis should be: bold, powerful, and intriguing. It was influential on a whole generation of Oxford philosophers - Gareth Evans, John McDowell, and Quassim Cassam most obviously, but also Susan Hurley, Bill Brewer, and others - but it has receded from view in the last twenty years. My aim in this essay is to determine what can be said in its favour. ${ }^{1}$

Here's the plan: in the first part of this essay (\$2), I'll explicate Strawson’s claim. In the second part $(\$ \$ 3-5)$, I'll reconstruct Strawson’s argument for his claim and identify the point at which it seems to me to fail. And in the third part (\$\$6-7) I'll use the failure of Strawson's argument to motivate a different connection between unity and objectivity, one which turns on the passivity of perceptual experience.

\section{The Thesis}

Unity

Strawson's thesis is that unity requires experience of an objective world. Each of these terms needs unpacking. Start with unity. We can distinguish two notions of unity of consciousness. On the first, 'the unity of consciousness at a time is the kind of unity involved when various contents of consciousness at a time... are all associated with one centre of consciousness, that is, are co-conscious' (Hurley, 1994, p. 55). On the second, the unity of consciousness concerns a subject's capacity to self-

\footnotetext{
${ }^{1}$ Some earlier discussions of Strawson's argument, to which I am indebted, include: (Bennett, 1968; Cassam, 1997; Harrison, 1970; Hurley, 1994; Rorty, 1970; Stevenson, 1982; Van Cleve, 1999, pp. 98-104; Walker, 1978, pp. 116-121)
} 
ascribe her experiences. Let a unified consciousness be one in which a set of experiences are co-conscious. And let a self-conscious subject be one who is capable of self-ascribing her experiences. These notions are distinct.

Strawson sometimes suggests that a subject who possesses a unified consciousness must be capable of self-ascribing her experiences: 'The notion of a single consciousness to which different experiences belong is linked to the notion of self-consciousness, of the ascription of an experience or state of consciousness to oneself... Unity of consciousness to which a series of experiences belongs implies, then, the possibility of selfascription of experiences on the part of a subject of those experiences' (1966, p. 98). This is unobvious. On the face of it, animals and (perhaps) infants possess a unified consciousness without being capable of selfascribing their experiences. So we would need further argument to show that a unified consciousness implies self-consciousness.

Once we distinguish a unified consciousness from self-consciousness, we can identify two claims linking unity and objectivity. First, that a unified consciousness entails objectivity. Second, that self-consciousness entails objectivity. On the assumption that self-consciousness entails a unified consciousness but not vice versa, the second claim is weaker than the first. But it is no less interesting for that. And since Strawson's argument for the claim that unity requires objectivity goes via considerations about the nature of self-consciousness, we do better to take self-consciousness as its starting point and put to one side issues about how a unified consciousness links up with the capacity to self-ascribe one's experiences.

\section{Objectivity}

What about objectivity? We can distinguish two broad notions of objectivity: an ontological notion and a perspectival notion. On the ontological notion of objectivity, something is objective when it doesn't dependent for its existence on minds and subjective otherwise. On the perspectival notion, whether or not something is objective turns on the extent to which it is tied to our point of view; things are objective to the extent that they are independent of a subject's point of view and subjective otherwise. 
These notions are distinct. The ontological notion of objectivity applies in the first instance to things. It is a constitutive notion of objectivity and since it cannot be a matter of degrees whether or not something depends for its existence on minds, the resulting notion of objectivity is all or nothing. The perspectival notion of objectivity applies in the first instance to ways of representing. Ways of representing are objective to the extent that they are accessible from more than one point of view or perspective. Maximally objective representations are those which are maximally independent of our point of view: representations of a world which is there anyway (to use Bernard Williams's phrase). Objectivity in this sense is a matter of degree: representations can be more or less objective since they can be more or less parochial.

These notions can be finessed in various ways, and it is better to think of them as picking out two broad ways of thinking about the objective/ subjective distinction. They each figure in Strawson's discussion and he doesn't distinguish them as carefully as one might like. Nevertheless his main concern in this section is with a version of the ontological notion. On Strawson's construal, something is objective iff it doesn't constitutively depend for its existence on a subject's act of awareness; and something is subjective iff it does constitutively depend for its existence on a subject's act of awareness (1966, pp. 98, 99, 100-101).

This way of drawing the objective/ subjective distinction is exhaustive and exclusive. But Strawson's thesis is sometimes put as the claim that unity requires objective experience, as in Bennett (1968, p. 345) and Rorty (1970, pp. 227-228). (Strawson himself uses the term 'objective experience' on only three occasions in The Bounds of Sense, each in his discussion of the Analogies.) And it is important to note that although the objective/ subjective distinction is exhaustive and exclusive, it does not follow that this is maintained when the distinction is embedded in experiential contexts. That is, although all the objects of awareness are either objective or subjective, it does not follow that they are all either experienced as objective or experienced as subjective: some objects of awareness may be experienced as neither. (Compare: the distinction between being made in India and not being made in India is exhaustive and exclusive, but it doesn't follow that everything is either experienced as 
being made in India, or as being not made in India. Some things - most things - are experienced as neither.) We can call this the Embedding Point.

\section{Experience}

Finally, experience. There are three different notions which need disentangling here. First and second, we need to distinguish experience which is of an objective world from experience which is merely as of an objective world. I take the former, and not the latter, to entail that there is an objective world. And third, Strawson also explicates his notion of experience of an objective world in terms of the possibility of making certain kinds of judgement:

\footnotetext{
We have already discussed what is taken to be implied by experience or awareness of objects, conceived of as distinct from any particular state of awareness of them. A judgement which claims objective validity purports to be true "no matter what the state of the subject may be"; experience of objects is possible only if objectively valid judgements are possible. (1966, p. 98)
}

Strawson here ties the possibility of having experience which is of or as of an objective world to a certain way of thinking about that world: experience which is as of an objective world is possible only if it is possible to make objectively valid judgements about the objects of experience, and experience which is of an objective world is possible only if it is possible to make true objectively valid judgements about the objects of experience.

There is a conflation in this passage between the possibility of conceiving of the objects of experience as distinct from any particular act of awareness of them and the possibility of making judgements about the objects of experience whose truth does not depend on how things are with the subject. The former is possible only if subjects possess a conception of objectivity: a conception of objects as objective. The latter is possible if subjects possess ways of thinking which as a matter of fact do concern things which are independent of the subject, even if the subject is not 
capable of thinking of those things as objective. ${ }^{2}$ I take Strawson's main concern - as evidenced in the first sentence of the above quote - to be the former. And this gives us a third element to Strawson's account of experience, namely that subjects who have experience of an objective world are in possession of a conception of objectivity - a way of thinking about objects as distinct from our acts of awareness of them.

I don't think that Strawson's blurring of these three notions of experience is exactly a conflation: he seems to me to take himself to have good reasons for thinking that subjects who have an experience which is either of or as of an objective world must thereby possess a conception of objectivity. But it will be more useful for our purposes if we keep the notions distinct. And once we do so, we can see that there are three ways one might link unity and objectivity:

$\left(\mathrm{E}_{1}\right)$ : Self-consciousness requires that subjects have experiences as of objective things.

$\left(E_{2}\right)$ : Self-consciousness requires that subjects have experiences of objective things.

(C): Self-consciousness requires that subjects possess the conception of things as objective.

This gives us three ways in which we might understand Strawson's thesis, and each figures at some point in his discussion. They will suffice to explicate the thesis. We can turn now to the argument.

\section{The Argument (1)}

Let an Objectivity Claim be one which links unity and objectivity. $\left(\mathrm{E}_{1}\right)$, $\left(\mathrm{E}_{2}\right)$, and $(\mathrm{C})$ are particular instances of objectivity claims. And let the consequent of an objectivity claim be an Objectivity Condition. According to what I will call the Concept Possession strategy, we argue for an objectivity claim as follows: first we argue that self-consciousness requires the possession of certain concepts; then we argue that the possession of

\footnotetext{
${ }^{2}$ This is one of the lessons of (Burge, 2010).
} 
those concepts requires the satisfaction of an objectivity condition. On this way of arguing, the possession of certain concepts provides the link between unity and objectivity.

If the Concept Possession strategy is going to convince, three questions need to be answered. First, what is involved in the capacity to self-ascribe one's experiences? Second, which concepts must be possessed by subjects who have the capacity to self-ascribe their experiences? And third, does the possession of any of those concepts require the satisfaction of an objectivity condition?

\section{Self-Ascription}

Start with the first question. There are a number of ways in which we might think about the self-ascription of experience. One natural thought is that in self-ascribing an experience as of p, I self-ascribe the episode of experiencing, including its content. For instance: I have a visual experience as of a red chair. I self-ascribe the episode of experiencing by making a judgement of the form: I'm having a visual experience as of a red chair. This way of thinking about self-ascription is suggested by some of Strawson's claims (1966, pp. 98, 108). Call it the Attitude Model of selfascription. What conditions does the Attitude Model place on selfconsciousness? And are there any concepts which subjects must possess in order for them to self-ascribe experiences in this way? ${ }^{3}$

The Attitude Model of self-ascription involves the subject making judgements about her own experiences. To this end, there are three different sets of concepts, the possession of which might plausibly be conditions on self-ascribing experiences:

1. Concepts of the Self: I'm experiencing a red chair

2. Concepts of Experience: I'm experiencing a red chair

3. Concepts of Empirical Objects: I'm experiencing a red chair

\footnotetext{
3 There are other ways of thinking about the nature of self-ascription, and it is interesting to consider what form the Concept Possession strategy would take on alternative models. I suspect that the most plausible alternatives would have the same implications as the Attitude Model, but it would require more space to determine whether this is so.
} 
Each of these sets of concepts gives us a different way of filling out the Concept Possession strategy, for each may require the satisfaction of an objectivity condition. And this gives us three possible routes for running the Concept Possession strategy: via concepts of the self, via concepts of experience, or via concepts of empirical objects.

We can turn now to the second and third questions above: is it true of any of these sets of concepts that they must be possessed by subjects who have the capacity to self-ascribe their experiences? And does the possession of any of these sets of concepts require the satisfaction of an objectivity condition? I'll take these questions together for each set of concepts in turn. If we can identify a concept which must be possessed in order for subjects to self-ascribe their experiences, and if the possession of that concept requires the satisfaction of an objectivity condition, then the Concept Possession strategy provides us with an argument from unity to objectivity.

\section{Concepts of Empirical Objects}

Strawson doesn't focus on the requirement to use the concepts of empirical objects in self-ascribing one's experiences in The Bounds of Sense, but it is a central claim in his 'Perception and Its Objects' (1979). One could use this thought to argue as follows:

It is part of the character of our experience that we experience a world of particular empirical things - e.g., trees, tables, cars. In self-ascribing such experiences, we need to make use of such empirical concepts in order to accurately capture the character of our experience. But grasping an empirical concept involves understanding that the referent of that concept can exist independently of one's experience of it: to grasp the concept of an ordinary physical object is to 'think that various modal and temporal properties are possessed by such an object: that it could have existed even if no one had ever observed it, that it could have been in existence now even though it was currently unobserved, and that it continues to exist even at times at which it is in fact unobserved' (Campbell, 2002b, p. 129). So selfascribing our experiences requires possessing a conception of things as objective. This would be a way of using the Concept Possession strategy to 
motivate an argument for the objectivity claim (C): that self-consciousness requires that subjects possess the conception of things as objective.

There are three problems with this argument. First, one might deny that grasping an empirical concept involves understanding that the referent of that concept can exist independently of one's experience of it. This is the view of Burge (2010), for example. Second, the argument starts from the claim that it is part of the character of our experience that we experience a world of particular empirical things. But if we are to get an argument from the bare capacity to self-ascribe one's experience, then we need an argument for the claim that any experience of a self-conscious subject must be one which presents itself to subjects as a world of particular empirical things. And we cannot support that claim by reflecting on the character of our own experience. Finally, if we granted the argument this missing claim - that any self-conscious experience must present a world of particular empirical things - then we would have, in effect, granted the objectivity claim $\left(E_{1}\right)$. But then the objectivity claim $\left(E_{1}\right)$ would itself require an argument in support.

\section{Concepts of the Self}

Unlike issues concerning our possession of empirical concepts, issues concerning the subject of self-ascription do feature centrally in Strawson's discussion. Two questions arise. First, is it the case that possession of a concept of self is required for self-consciousness? And second, if so, does the possession of that concept require satisfaction of an objectivity condition?

Strawson doesn't explicitly address the first question, but one might object that we are not entitled to assume that self-ascription requires use of the first-person for one might self-ascribe an experience in the impersonal form 'there is an experience as of p'. This is the objection that Lichtenberg raises to Descartes's use of the first-person in formulating the cogito and it can be deployed here to challenge the claim that self-ascription requires possession of the concept of the self. 
What should we make of this objection? The issue is whether we should think of a judgement of the form 'there is an experience as of $\mathrm{p}$ ' as a form of self-ascription. One reason to think not is that it is not enough for a judgement to count as a self-ascription that it ascribes something to the thing which (as it so happens) is identical to the subject making the judgement. Self-ascription requires, further, that I ascribe the property in question to myself under a first-personal mode of presentation. Consider: If I catch sight of myself in the mirror and, without recognising that I am looking at myself, judge 'he looks tired', I have not self-ascribed the property of looking tired. Since judgements of the form 'there is an experience as of p' do not look to ascribe experiences to anything, still less under a first-personal mode of presentation, this might motivate the claim that they are not forms of self-ascription.

A second problem concerns the difference between 'there is an experience as of $\mathrm{p}$ and there is an experience as of q' and 'there is an experience as of $\mathrm{p}$ and q'. Bernard Williams (1978, pp. 95-101) has argued that the Lichtenberg formulations can only capture this distinction by relativizing the judgements to a place in a way which reintroduces the notion of a subject. Someone who thinks that the self-ascription of experiences requires subjects to draw a distinction between these states of affairs has licence to deny that the Lichtenberg judgements are forms of selfascription.

Let us accept, then, that the concept of a self is required in order to selfascribe experiences. Still, the question arises: which concept of a self? There are two lines one might take on this. First, one might hold that selfascription requires possession of the concept of the empirical subject. This is what Strawson calls personal self-consciousness, one which involves 'the full conditions for ordinary empirical self-ascription of experiences' ( $\mathrm{p}$. 107), including 'the existence of the subject as an intuitable object in the world' (p. 106). Or one might hold that self-ascription requires possession of the concept of the transcendental self. Strawson calls this transcendental self-consciousness, 'the necessary self-reflexiveness of a possible experience in general' (p. 107). I will call these the concepts of the empirical subject and transcendental subject respectively. 
Does the possession of either of these concepts require the satisfaction of an objectivity condition? Consider first the concept of the transcendental subject. One worry is that, as Kant says, this concept 'has no content' (A381); it 'contains no manifold in itself and is always one and the same in every judgement, because it is merely the formal element of consciousness' (An 4: 141-2). ${ }^{4}$ It is hard to see how such a purely formal concept could require the satisfaction of any objectivity condition: the content of the concept of the transcendental subject is too empty to place any conditions on how things must be in order for subjects to possess the concept. Indeed, when Strawson attempts to motivate a link from transcendental self-consciousness to the satisfaction of an objectivity condition, he goes via the requirement that transcendental self-consciousness require possession of concepts of experience rather than via the concept of the transcendental subject. This first option does not look like a promising route. $^{5}$

In contrast, the concept of the empirical subject looks much more suitable to feature in an argument for the satisfaction of an objectivity condition, and this is how Strawson's argument from personal self-consciousness proceeds. Strawson claims that ascribing an experience to the empirical self requires 'empirically applicable criteria of identity for subjects of experience' (p. 102) and 'these criteria, though not the same as bodily identity, involve an essential reference to the human body' (p. 164). If this is right, then grasp of the concept of the empirical self involves understanding that it is 'a corporeal object among corporeal objects' ( $\mathrm{p}$. 112). This looks like an argument for (C): the claim that selfconsciousness requires that subjects possess a conception of objectivity.

\footnotetext{
${ }^{4}$ Kant texts are cited by the volume and page number in the Academy Edition of Immanuel Kant, Gesammelte Schriften (Berlin: Walter de Gruyter and predecessors, 1900-), with the exception of the Critique of Pure Reason which is cited in the standard A/B format. Short titles and abbreviations are used to indicate the work in question.

${ }^{5}$ One might think that - even on this attenuated notion of a subject - if we must think of our experiences as determinations of a subject, we must therefore think of that subject as independent of those experiences in a way which suffices for thinking of that subject as objective. This would be to endorse a unity to objectivity argument which went via the concept of the transcendental subject. But some of Kant's immediate successors have seen his remarks about the emptiness of the representation ' $\mathrm{I}$ ' as showing precisely that it is compatible with thinking of one's experiences as determinations of a subject that one take those experiences to constitute the subject. See (Beiser, 2002) for some discussion.
} 
There are two main failings with this argument. First, one might object to the claim that self-ascription requires ascribing experiences to an empirical subject. To take this line is to say that the capacity for self-ascription requires no more than that which is involved in transcendental selfconsciousness. Second, even if we grant that self-consciousness requires the ascription of experiences to the empirical self, there are no grounds for thinking that we must think of that self as a corporeal object, amongst other corporeal objects in the world: idealistic alternatives may be available which don't build into them a conception of objectivity. Strawson's argument against these options here is premised on his commitment to (as he sees it Kant's) principle of significance, the claim that 'there can be no legitimate, or even meaningful employment of ideas or concepts which does not relate them to empirical or experiential conditions of application' (p. 16). And without this verificationist assumption, the move from possession of the concept of the empirical subject to the possession of a conception of objectivity does not go through. ${ }^{6}$

To summarise: we have looked at two options for enacting the Concept Possession strategy. The first - concerning the concepts of empirical objects - foundered because we were given no reason to think that the possession of such concepts really is a condition on self-consciousness. And the second - concerning concepts of the self - foundered on a dilemma. Either such a concept is purely formal, in which case there is no plausible link to objectivity, or it is empirical and has a link to objectivity, in which case there are no grounds for thinking that it is a genuine condition on self-consciousness.

\section{The Argument (2)}

\section{Concepts of Experience}

This leaves us with the claim that concepts of experience are a condition on self-consciousness. This is a more plausible starting point for the Concept Possession strategy, and it is where the centre of Strawson's discussion resides. The heart of the argument is contained in one epigrammatic sentence:

\footnotetext{
${ }^{6} \mathrm{I}$ discuss these issues in greater detail in (Gomes, 2011).
} 
'This is how things are (have been) experienced by me as being' presupposes 'This is how things are (have been) experienced as being'; and the latter in turn presupposes a distinction, though not (usually) an opposition between 'This is how things are experienced as being' and 'Thus and so is how things are'. (p.108).

Rorty summarises this move as follows: 'The point Strawson is making here is that you don't know what "experience" means if you don't know what "seems to me..." means, [and] that you don't know what that means unless you know that something can seem to me to be $\mathrm{X}$ and not be $\mathrm{X}$ ' (Rorty, 1970, p. 213). That is: self-consciousness requires that subjects possess the concept of experience; possession of this concept requires that subjects grasp the distinction between how things are and how things appear; and this distinction comprises a conception of things as objective.

The argument is noticeable in its brevity. Many of those who have commented on the argument - Walker (1978, p. 118), Stevenson (1982, p. 325), Van Cleve (1999, p. 104) - note that if it is good, it supports only the claim that self-consciousness requires possession of the conception of things as objective, the claim I labelled (C) above. And (C) falls short of establishing that there is anything in the world which is objective. We can put this objection to one side for the moment and instead focus on the argument inasmuch as it is as an argument for (C). Let us consider its starting point: the claim that subjects must possess the concept of experience in order to self-ascribe their experiences. What should we say about this claim?

One response is to deny the claim and hold that subjects can self-ascribe experiences without using the concept of experience. Ross Harrison (1970) suggests a response along these lines. Someone who lacked the concept of experience, Harrison claims, would still be able to distinguish between her experiences, to recognise this experience as vivid, and this as muted. In recognising her experiences as vivid and muted, she would be capable of identifying and describing her experiences. This is a form of self-ascription, Harrison suggests, even though the subject lacks the concept of experience. In virtue of lacking that concept she would not, to use Harrison's phrase, be able to do the philosophy of her situation (1970, pp. 219, 220), but not 
being able to do the philosophy of one's situation is not the same as not being self-conscious (the conceit of philosophers notwithstanding).

Harrison's objection requires that one can pick out an experiential state and describe it without one's judgements being 'informed by a grasp of their [the experiences'] subjective status' (Cassam, 1997, p. 104). And this is something that Strawson might deny. Still, even if Harrison is wrong to think that one can pick out and describe an experiential state without some concept of experience, we can ask why we must do this with the concept of experience specifically as opposed to some other experiential concept. Most obviously, many of our perceptual experiences can be self-ascribed using the concept of perception rather than the concept of experience: I'm seeing a red chair. This bears on Strawson's argument, because he assumes - in Rorty's formulation - that a self-ascription of experience requires one to 'know that something can seem to me to be $\mathrm{X}$ and not be $\mathrm{X}$ '. But the concept of perception is a success notion, so it can be no condition on using the concept of perception to self-ascribe experiences that one understand that something can be perceived to be X and not be X - for nothing can be perceived to be $\mathrm{X}$ and not be $\mathrm{X}$.

This objection suggests that we need to be more careful in formulating the link between possession of a concept of experience and a conception of objectivity. Strawson and Rorty argue for the connection via what we can call the fallibility of experience, understood as follows:

Fallibility of Experience: there are cases in which it is experienced as if $\mathrm{p}$ and not $\mathrm{p}$.

And they assume that possession of the concept of experience requires a grasp of the fallibility of experience, and that grasp of the fallibility of experience suffices for the possession of a conception of objectivity.

Since possession of the concept of perception does not require a grasp of the fallibility of experience, we cannot follow this route when thinking about concepts of perception. But consider the partiality of perception (Kalderon, 2007, pp. 572-573), understood as follows: 
Partiality of Perception: there are cases in which $\mathrm{p}$ and it is not the case that it is perceived that $\mathrm{p}$.

If possession of the concept of perception requires a grasp of the partiality of perception, and if that grasp of partiality suffices for the possession of a conception of objectivity, then there would be a route from possession of the concept of perception to the objectivity condition in (C).

I won't set out how Strawson might defend each of those claims here, though both seem to me to be plausible. The distinction drawn between Level-1 and Level-2 perspective-taking in developmental psychology seems, for instance, both to evince a distinction between fallibility and partiality and to assume that a grasp of partiality is required for children to be ascribed the concept of perception. ${ }^{7}$ And the idea that possession of the concept of perception involves a grasp of partiality seems linked to the idea that possession of the concept of perception involves a grasp of the enabling conditions for perception, an idea suggested by Strawson (1974a) and developed by Evans (1980). Granted these claims, the upshot of the discussion thus far is that the distinction between fallibility and partiality does not trouble Strawson's argument so long as the concepts of experience and perception require a grasp of one or the other, and so long as grasp of either suffices for the possession of a conception of objectivity.

\section{Original Intuition}

But this raises a more serious question: are there not other broadly experiential concepts which we can use to self-ascribe experiences, some of which carry with them no connotations of objectivity? Consider the concept of an episode of awareness, the undergoing of which served to

\footnotetext{
${ }^{7}$ In summary: children who can perform Level-1 perspective-taking tasks are capable of understanding that whether or not someone can see something, say, depends on whether there is something occluding the object in her line of sight. This competence develops at around two-and-a-half to three years. Level-2 perspective taking kicks in at around four to four-and-a-half years. These competencies involve understanding that something which is white will appear red to someone who looks at it through a red filter. One way to explicate this distinction is in terms of the distinction between Partiality and Fallibility. Level-1 perspective taking involves grasp of the partiality of perception. Level-2 perspective taking involves grasp of the fallibility of experience - that things can appear to be other than how they are in the world. See (Nudds, 2011) for discussion.
} 
constitute the objects of that episode of awareness. I will call such an episode of awareness 'original intuition', following Kant's description of original intuition as 'one through which the existence of the object of intuition is itself given...' (B72). Could one use the concept of an original intuition to self-ascribe experiences? Someone who did so would selfascribe their experiences with a judgement of the form: I am originally intuiting a red chair. And since the concept of an original intuition does not, on the face of it, require any grasp of a distinction between how things appear and how things are, it looks like someone who self-ascribed experiences in this way would not be required to possess a conception of things as objective. This would be a fatal objection to any attempt to run the Concept Possession strategy via concepts of experience.

Strawson seems to have recognised something like this worry. One of the objections he considers to his account is the possibility of a sense-datum experience, one on which 'there was no distinction to be drawn between the order and arrangement of the objects... and the order and arrangement of the subject's experiences of awareness of them' (p. 99). I say 'seems to have recognised', because Strawson seems to me to mischaracterise the issue. When the spectre of a sense-datum experience arises - first at pp.98-101, then at pp.109-110 - Strawson's focus is on a particular sort of experience, and whether that sort of experience is subject to the unity of consciousness. But at this stage of the argument, the issue is not whether a subject who has only sense-data experiences could selfascribe her experiences, but whether a subject who possessed only the concept of a sense-datum experience - the concept of an original intuition - could use that concept to self-ascribe her experiences. If she could not, then there are grounds for thinking that the concepts we must use to selfascribe our experiences require possession of the conception of things as objective.

One might think the worry somewhat abstruse. After all, as Kant says, the concept of an original intuition is one 'so far as we can have insight, can only pertain to the original being' (B72). This is not Strawson's response. He suggests instead that the possession of such a concept would only be possible for someone who independently possessed a conception of things as objective. That is, the concept of an original intuition cannot stand 
alone. 'The minimum implied is that some at least of the concepts under which particular experienced items are recognized as falling should be such that the experiences themselves contain the basis [for a distinction between how things appear and how they are]' (p. 101).

What grounds are there for thinking that the concept of an original intuition could only be possessed by someone who possessed the concept of experience? It is striking that Strawson states this claim without argument. If the concept of an original intuition is not parasitic on the concepts of experience or perception, then the Concept Possession argument in support of (C) fails. So one would expect the claim that the concept of an original intuition is parasitic to be in need of attention and support. The failure to provide an argument for this claim threatens to shipwreck the entire argument.

I suspect what is going on here is a background acceptance of what has come to be known as Wittgenstein's Private Language Argument, at least on one certain gloss of how that argument proceeds. Strawson doesn't mention Wittgenstein by name in this section - Wittgenstein is only mentioned once in The Bounds of Sense, as a contrast with Kant's inattention to the social aspect of concept possession (p. 151) - but both Jonathan Bennett (1966, p. 204) and Ross Harrison (1974, p. 61) make a connection to Wittgenstein explicit in their own unity to objectivity arguments. Harrison's invocation of Wittgenstein is of particular interest since his book is based on the DPhil he wrote under Strawson's supervision.

Why would Wittgenstein's remarks about the possibility of a private language be relevant? Strawson's understanding of these passages is set out in his critical notice of the Philosophical Investigations published in Mind (1954; citations to the $1974 \mathrm{~b}$ reprint). Strawson takes Wittgenstein to show that 'names [for the items picked out by a private language] must always contain in a more or less complex way... some allusion to what is not sensation, to what can be seen and touched and heard' (p. 153). More specifically, on Strawson's reading Wittgenstein makes two claims: that a private language collapses the distinction between 'seems right' and 'is right', and that it is a condition on possessing sensation concepts that there 
are concepts for which the seems right/ is right distinction applies. These parallel the claims that Strawson makes about the sense-datum experience - or, in the terms I have used, about the concept of an original intuition. For if one takes the concept of an original intuition to collapse the distinction between how things seems to the subject and how things are to the subject, then the upshot of Wittgenstein's claims, on Strawson's construal of them, will be that possession of the concept of an original intuition requires possession of concepts for which there is a seems/ is distinction.

This conjecture may serve to explain why Strawson doesn't offer any reasoning in support of the claim that the concept of an original intuition can only be possessed by someone who already possesses the concepts of experience or perception, but it doesn't obviate the need for such reasons to be provided - and simply gesturing towards Wittgenstein's remarks on the impossibility of a private language won't suffice to provide such reasons. In order for this gap in Strawson's argument to be filled, a number of tasks would need to be completed. First, Strawson's reading of these passages in Wittgenstein would need to be spelled out and evaluated. Second, we would need reason to think that the conclusions Wittgenstein reaches about the impossibility of using only a private language to pick out sensations can be transferred over to the impossibility of using only the concept of an original intuition to pick out episodes of awareness. And finally, we would need to be convinced that there was no other way to secure that possibility other than by a subject also possessing concepts for which there is a seems/ is distinction.

To put the point bluntly: Wittgenstein's remarks on the possibility of a private language are difficult to understand and contested in their interpretation, so a reconstruction of the Transcendental Deduction of the Categories which appeals, at a key point, to the results of the Private Language Argument is at risk of elucidating the obscure by the obscurer. The Concept Possession strategy fails if it cannot rule out the possibility of our self-ascribing our experiences using only the concept of an original intuition and, as things stand, we only have a vague promissory note that this deficit can be filled. 


\section{The Argument (A Coda)}

The Concept Possession strategy so far has presented us with an argument objectivity claim $(\mathrm{C})$ : that self-consciousness requires subjects to possess a conception of objectivity. What about claims $\left(\mathrm{E}_{1}\right)$ and $\left(\mathrm{E}_{2}\right)$ ? This is where Strawson's discussion of the nature of sense-datum experience itself - as opposed to the concept of a sense-datum experience - is relevant. For what we need to complete an argument for $\left(E_{1}\right)$ and $\left(E_{2}\right)$ is an argument from possession of a conception of objectivity to objective experience, and Strawson looks to support such a move by arguing for the supposed contrapositive: that subjective experience is incompatible with the possession of a conception of objectivity (pp. 98-100). Sense-datum experience, Strawson says, consists of 'impressions which neither require, nor permit of, being "united in the concept of an object" in the sense in which Kant understands this phrase' (p. 99). If subjects had nothing but this form of experience, they would not possess a conception of objectivity. So subjective experience entails lack of possession of a conception of objectivity. If the supposed contrapositive holds, then possession of a conception of objectivity requires objective experience. And this looks to complete the argument from $(\mathrm{C})$ to either $\left(\mathrm{E}_{1}\right)$ or $\left(\mathrm{E}_{2}\right)$ depending on whether it is experience of objective things which is needed to possess a conception of objectivity or merely experience which is as of objective things.

The problem with this move is that it falls foul of the Embedding Point noted above. Strawson argues for the claim that possession of a conception of objectivity requires objective experience by arguing for the claim that subjective experience entails lack of a conception of objectivity. But this inference goes through only on the assumption that the distinction between subjective experience and objective experience is exclusive and exhaustive. And as we noted above, this doesn't follow from the fact that the subjective/ objective distinction is exclusive and exhaustive. From the fact, if such it be, that subjective experience cannot ground a conception of objectivity, we cannot conclude that possession of a conception of objectivity require objective experience because we cannot assume that if experience is not subjective then it must be objective. So long as it is possible that there are some experiences which don't present objects as 
either subjective or objective, then there is a gap in the final part of Strawson's argument which has not been filled.

For a sense of why this gap matters, consider John Campbell's recent argument 'we cannot extract the conception of a mind-independent world from a mind-dependent image' (Campbell, 2002a, p. 135). Campbell writes:

On the common factor view, all that experience of the object provides you with is a conscious image of the object. The existence of that conscious image is in principle independent of the existence of the external object. The existence of the image, though, is dependent on the existence of the subject who has the conscious image. So if your conception of the object was provided by your experience of the object, you would presumably end by concluding that the object would not have existed had you not existed, and that the object exists only when you are experiencing it. We cannot extract the conception of a mindindependent world from a mind-dependent image; this is the traditional problem with Locke's doctrine of abstraction. (Campbell, 2002a, pp. 134-135)

There are two problems with the argument in this passage. First, Campbell assumes that if the existence of the image is dependent on the subject who has the conscious image, then that dependence shows up in the experience itself. That is: experience which is subjective is presented as being subjective. Nothing is said to justify this claim. And second, Campbell moves from this argument to the claim that experience must present you with mind-independent objects. But this is what the Embedding Point calls into question. For there may be forms of experience in which things are neither presented as objective nor subjective, and no argument has been given for holding that we cannot extract the conception of a mindindependent world from those forms of experience.

One might aim to neuter the force of the Embedding Point by asking just what it would be for an experience to present things as neither objective nor subjective. If we can make no sense of the notion, then this line of objection may be blunted. But this response just calls into question our 
initial grasp on the notions of experience presenting things as objective or subjective. What is it for experience to be of or as of objective things? Any argument which wants to establish $\left(\mathrm{E}_{1}\right)$ or $\left(\mathrm{E}_{2}\right)$ cannot take these notions for granted.

Where does this leave us? We're now in a position to formulate Strawson's argument as a series of conditionals:

1. The self-ascription of experiences requires possession of the concept experience

2. Possession of the concept of experience requires possession of a conception of objectivity

3. Possession of a conception of objectivity requires experience which is of (or as of) objective things.

We have seen that the first claim needs to be handled carefully: there are a range of broadly experiential concepts which we can use to self-ascribe experiences, including the concept of perception. And the most serious problem with this first claim is that there look to be ways of self-ascribing one's experiences which make use of concepts the possession of which doesn't require grasp of a conception of objectivity, concepts such as that of an original intuition. Strawson's suggestion is that our capacity to ascribe experiences using such a concept turns on our possessing the concepts of perception and experience and thus even the possibility of ascribing experiences using the concept of original intuition requires a conception of objectivity. But no argument for this claim is given in Strawson's text.

One lesson here concerns Strawson's failure to distinguish his project from Kant's own. Consider the following response on Strawson's behalf to my objections above:

You say that Strawson has not shown that the self-ascription of experiences requires possession of the concept experience because subjects could selfascribe experiences using the concept of an original intuition. But we don't 
use such a concept. And philosophy - at least, as undertaken by Strawson - is an exercise in descriptive metaphysics, one of describing 'the actual structure of our thought about the world' (Strawson, 1959, p. 9). So if the actual structure of our thought about the world makes use of selfascriptions using the concept of experience, then we do not need to worry about some idiosyncratic alternative.

The failure here is to distinguish the Kantian project of identifying necessary conditions on the experience of an objective world with the descriptive project of describing our own conceptual scheme. Our conceptual scheme may make use of the concept of experience when selfascribing experiences, but this doesn't show that the use of that concept is necessary for any form of self-consciousness. If the aim is to show that any being that is self-conscious must undergo experience of an objective world, then we cannot rest content with simply describing how it is that we selfascribe experience.

\section{An Alternative (1)}

What can we learn from Strawson's discussion? The question which lies at the heart of Strawson's discussion is the question of how we must think of experiences if we are to self-ascribe them. If self-ascribing our experiences requires us to think of those processes as episodes of perception or experience - ways of thinking of experiences which bring with them a conception of objectivity - then there are grounds for thinking that a unity to objectivity argument for (C) can be established. But if we are able to self-ascribe them whilst thinking of them as inventive acts which create the objects of our experience, then the prospects for such an argument look slim.

Let us try a new tack. One of Kant's central claims in the first Critique is that our perceptual capacities are receptive:

There is no doubt whatever that all our cognition begins with experience; for how else should the cognitive faculty be awakened into exercise if not through objects that stimulate our senses and in part themselves produce representations... (B1) 
[W] will call the receptivity of our mind to receive representations insofar as it is affected in some way sensibility... It comes along with our nature that intuition can never be other than sensible, i.e., that it contains only the way in which we are affected by objects. (A51/B75)

Kant's most basic characterisation of this faculty is as passive. He writes:

Representations in regard to which the mind behaves passively, and by means of which the subject is therefore affected ... belong to the sensuous cognitive faculty... The lower cognitive faculty has the character of passivity of the inner sense of sensations... (An 7:140-1)

But the senses are wholly passive, they necessarily require an object (DWL 24:706)

Let us take the passivity of perceptual experiences to reside in the fact that the inception and character of perceptual events depends on the objects perceived. Someone who accepts the passivity of perception does not and should not claim that there can be no active element to episodes of perceiving: looking, listening, noticing are things that we $d o$, and these episodes are governed by forms of activity. But they depend on there being a passive element to perceptual experience: looking, listening and noticing can only take place against the background of perceptual episodes whose inception and character depends on the objects perceived.

This passive element to perceptual experience is emphasised by Strawson, most centrally in his 'Causation in Perception' (1974a). It features in Evans's work, particularly in his commentary on Strawson (1980). Both cash it out - as Kant did - in terms of a causal relation holding between perceiver and perceived object. I refrain from this further characterisation to leave open the possibility that perceptual experience can be passive to its objects without those objects being the cause of the perceptual experience. ${ }^{8}$

\footnotetext{
${ }^{8}$ I have in mind those naive realist views which take objects to be constitutive of perceptual experience. See (Child, 1994; Snowdon, 1980) for discussion, and (Gomes, forthcoming) for the development of a Kantian form of naïve realism.
} 
Perception is passive to its objects. This is a claim about perception itself. How does this show up in our ways of thinking about perception? Strawson (1974a) famously defends the claim that our concept of perception is a causal concept. I take Strawson to mean by this that it is a requirement on operating with a concept of perception that one think of perception in causal terms. Someone who is sympathetic to this claim should also think this to be true of the passivity of perception: it is a requirement on operating with the concept of perception that one think of perception as passive to its objects. Call this the Conceptual Passivity Claim. ${ }^{9}$

Some considerations in favour of this claim concern what Evans called the enabling conditions on perception: it looks like someone who is capable of self-ascribing her perceptual experiences using the concept of perception has to understand that there are various disabling conditions for her perceptual experience - that her visual experience will cease if something occludes her view; that her auditory experience will cease if she covers her ears; and so on. These enabling and disabling conditions reflect the fact that perception is passive to its objects. And if grasp of the concept of perception involves understanding the enabling and disabling conditions involved in perceptual experiences, it involves an understanding of the passivity of perception. These considerations seem operative in some of the developmental psychology work on when children acquire the concept of perception.

If the concept of perception is a passive concept, then someone who selfascribes her perceptual experiences using the concept of perception thereby recognises that her perceptual experiences are passive to their objects. ${ }^{10}$

\footnotetext{
${ }^{9}$ Paul Snowdon has criticised the idea that the concept of perception is a causal concept in a series of papers: $(1980,1990,1998,2011)$. It is an interesting question whether his arguments apply against the claim that the concept of perception is a passive concept. Some of them at least seem to me to be ineffective against the latter claim.

${ }^{10}$ What about the self-ascription of sensations? I take at least standard cases of bodily sensation to be presented to us as modes of the body, located in various body parts. And the self-ascription of these sensations requires us to think of ourselves as passively related to the body part in question. This is compatible with our thinking of the modes themselves as determined by our act of awareness of them. See (Gomes, 2011; Hyman, 2003) for defence of the claim that sensations are presented as located in the body. More would need to be said to determine whether this proposal applies to all cases of sensation.
} 
What about someone who self-ascribes her experiences using the concept of experience? Must she think of her experiences as passive in any way? An argument that she must can be taken from Strawson's discussion of the character of perceptual experience in his 'Perception and Its Objects'. Strawson imagines someone who is asked to describe the character of his perceptual experience whilst remaining neutral on the question of whether things are as they seem to him to be:

Our observer is quick on the uptake... He says... the simplest way to do this, while remaining faithful to the character of the experience as actually enjoyed is to put my previous report in inverted commas or oratio obliqua and describe my visual experience as such as it would have been natural to describe in these terms, had I not received this additional instruction. Thus: "I had a visual experience such as it would have been natural to describe by saying that I saw, etc. . . . [or, to describe in these words, 'I saw . . . etc.'] was it not for the obligation to exclude commitment to propositions about independently existing objects." (Strawson, 1979, pp. 43-44)

One point to take from this passage is that a subject who self-ascribes an experience using the concept of an experience understands her experience to be subjectively similar to a perception of things being a certain way. On this way of thinking about the relations between the concepts of perception and experience, the concept of perception comes first and the concept of an experience is the concept of a state which is subjectively indiscriminable from a perception of a certain sort. ${ }^{11}$ If this is right, then a subject who self-ascribes her experiences using the concept of an experience is thinking of her experience as being subjectively similar to a perceptual state which is passive to its objects. So passivity enters here too.

\footnotetext{
11 This won't quite do, so long as there can be experiences which present things in ways that perception could not, for example, the hallucinatory experiences of Escher staircases. Peacocke (2005) suggests that we might think of such experiences as having multiple similarities to distinct perceptions, even though there is no one perception to which they are similar. An alternative is to deny that there can be such cases: after all, there are cases in which a particular viewpoint on a carefully constructed model can give rise to a perceptual experience in which it genuinely seems to one as if one is presented with an Escher staircase, though of course one isn't.
} 
What about the concept of an original intuition? An original intuition is not passive to its objects: it creates its objects. Does this show up in the concept of an original intuition - must a subject who makes use of the concept of an original intuition take her originally intuitive experiences are active in regard to their objects? The corresponding claim for the concept of original intuition holds that it is a requirement on operating with the concept of an original intuition that one think of original intuition as active to its objects. Call this the Conceptual Activity Claim.

There are a number of ways to make this claim plausible. Most obviously, the concept of an original intuition is a philosopher's invention, so it's hard to see how someone could possess it without understanding original intuition's nature as a creative act. More generally, one would expect the converse of Evans's point about enabling conditions to apply: someone who self-ascribes her experiences using the concept of an original intuition should refrain from certain activities - moving around the object to get a better view of it; taking it outside to see it in a better light - and her refusal to engage in these activities should make plausible that the creative nature of an act of original intuition is understood by someone who makes use of the concept.

Strawson's argument from unity to objectivity centred on the question of whether we must think of our experiences as episodes of perception or experience - ways of thinking of experiences which bring with them a conception of objectivity - or whether we could think of them as inventive acts which create the objects of our experience. If the Conceptual Passivity and Conceptual Activity Claims are true, we can transpose the issues raised by Strawson's argument into the key of passivity and activity and reformulate the questions as follows: may a self-conscious subject think of her experiences as active in regards to their objects - or must she think of at least some of her experiences as passive to their objects? If the latter is true, then someone who is capable of self-ascribing her experiences must understand the passivity of perception. And if grasp of the passivity of perception requires the possession of a conception of objectivity, then we have the outlines of an argument for the objectivity claim (C). 


\section{An Alternative (2)}

Can such an argument be made? Perhaps. One of the great themes of Kant's Critical writings is that we are finite beings, and that our finitude impresses itself upon us in various ways (B72, B138-139; CPJ 5:407; see (Moore, 2003) for discussion). One aspect of our finitude is the fact that we are passively related to the objects of our experience. And one way in which our finitude impresses itself upon us is through our being aware of ourselves as passively related to the objects of our experience: 'the difference [is] noticed between representations given us from somewhere else and in which we are passive, and those that we produce simply from ourselves and in which we show our activity' ( $G$ 4:451). We are passively related to the objects of perceptual experience and we are aware of ourselves as passively related to the objects of perceptual experience.

There are two forms this awareness might take. One is conceptual awareness, of the sort that, when things go well, amounts to knowledge. Kant's sometimes suggests that we all know, or are at least are all in a position to know, that we are passively related to the objects of experience: such knowledge 'is to be found even in the most common understanding' (G 4:451-2); 'In analytic philosophy, I simply make obscure representations in the soul clear. For all propositions of philosophy are known to everyone...' ( $A M$ 25:1221-2). This would certainly give us an easy route to objectivity. For if we already know that we are passively related to the objects of experience, and if grasp of the passivity of experience requires possessing a conception of objectivity, then the knowledge that we are passively related to objects would entail the possession of a conception of objectivity. But this wouldn't give us a route from unity to objectivity since all the work is being done here by the assumption that we know ourselves to be passively related to the objects of experience rather than any claim about the possibility of a subject selfascribing her experiences. Unity has dropped out of the argument.

A second form of awareness is intuitional awareness, of the sort which Kant thought put us in immediate contact with objects. Cassam explains this notion as follows: 'Crudely, to conceive of something as $[\mathrm{F}]$ is to think of it as such, but to be intuitively aware of something as $[\mathrm{F}]$ is to 
experience or perceive it as [F]' (Cassam, 1997, p. 8, my amendments in square brackets). Thus, to say that we are intuitionally aware of ourselves as being passively related to the objects of experience is to say that we experience ourselves as passively related to the objects of experience. One way to make sense of this is to distinguish those aspects of the character of our experience which are determined by the objects of experience, and those aspects of the character of our experience which are determined by the way in which we are aware of objects (see, e.g., Soteriou, 2013, pp. 111-114). Kant himself marks something like this distinction when distinguishing the matter of intuition from its form. The passivity of perceptual experience is a structural feature of our experience of objects it is an aspect of the way in which we are related to objects - and in being aware of ourselves as being passively related to the objects of experience, we are aware, in intuition, of that structural feature of our experience.

Say that we are so aware of being passively related to objects. Then the passivity of perceptual experience is transparent to us in a certain way: it shows up in perceptual experience. In doing so, it impresses itself upon us such that we cannot help but recognise that passivity when self-ascribing our experiences. Thus a self-conscious subject who wants to accurately selfascribe her experiences must be capable of using experiential concepts which capture that passivity, concepts such as those of experience and perception. We seem to be passively related to the world. And if we want to capture that when self-ascribing experiences, we need to make use of the concepts of perception and experience, concepts which evince a grasp on the passivity of perceptual experience. Since grasp of the passivity of perceptual experience requires a conception of objectivity, the selfascription of transparently passive experiences requires a conception of objectivity.

We can put this line of thought into a schematic argument for the objectivity claim (C):

1. Our experience seems to us to be passive to its objects

2. In self-ascribing experiences which seem to us to be passive to their objects, we must be capable of using concepts the application of which demonstrates an understanding of the passivity of experience. 
3. The possession of such concepts requires the possession of a conception of objectivity.

These claims are in need of elucidation and defence, but together they provide the framework for a unity to objectivity argument which turns on the passivity of experience.

How does this way of moving from unity to objectivity relate to Strawson's argument? First, there's a sense in which this line of thought is strikingly unStrawsonian. Prima facie one might think that Strawson would be sympathetic to the idea that our experience seems to us to be passive to its objects. This might be thought to be the lesson of 'Perception and its Objects', perhaps when combined with the lessons of 'Causation and Perception'. But consider Strawson's failure in The Bounds of Sense to distinguish the Kantian project of identifying necessary conditions on objective experience with his own project of describing our own conceptual scheme. The starting point for the line of thought suggested above is a claim about how things seem to us to be. If this is going to support a claim about how things must be, the 'our' here must range over all self-conscious beings, and it must be a claim about how things necessarily seem to us to be. But that means it can't be supported, Strawson style, by reflection on how things actually seem to us, of the sort that Strawson offers us in 'Perception and its Objects'. It needs to be supported by considerations about the structural nature of sensible intuition, considerations of the sort that Kant offers us (A19/B33, A51/B75, A68/B93). It is unclear whether Strawson has the resources to offer that kind of argument - but we might hope that Kant has additional tools.

Second, I mentioned above Ross Harrison's charge that Strawson's argument shows only that subjects who lack a conception of objectivity cannot do the philosophy of their situation and that, contrary to Strawson, one can be unable to do the philosophy of one's own situation without failing to be self-conscious. The line of thought sketched above in effect assumes that Harrison's objection has no force - for it assumes that the passivity of perceptual experience is transparent to us in such a way that a self-conscious subject has to think of her experiences as passive to their 
objects if she is going to self-ascribe them. If this can be defended - and I don't know whether it can - then there would be a sense in which selfconscious subjects would have to be able to do the philosophy of their own situation. That seems to me a very Kantian thought. And it seems to me a very Strawsonian thought as well.

\section{Conclusion}

Let me conclude. Strawson's discussion in the section 'Unity and Objectivity' of The Bounds of Sense aims to secure what he took to be the central insight of Kant's transcendental deduction of the categories: that unity of consciousness requires experience of an objective world. I've tried to outline one central argument in that discussion which turns on the requirement that self-ascribing subjects possess a concept of experience. And I've suggested that this argument fails in being unable to rule out the possibility of subjects self-ascribing their experiences using only the concept of an original intuition.

Strawson's argument can be remade if there are ways in which we must think of our experiences if we are to self-ascribe them, and if those ways of thinking about experience require the possession of a conception of objectivity. Drawing on Kant's account of the structural features of intuition, I've tried to suggest that we have to think of our experiences as passive to their objects, at least if we are going to capture the way in which our experiences present themselves as passive to their objects. This means that someone who self-ascribes her experiences must be capable of thinking of them as passive to their objects. And if grasp of the passivity of experience requires a conception of objectivity, then the possibility of a subject self-ascribing her experiences requires that she possess a conception of objectivity. It is the self-conscious passivity of our perceptual experience which offers us the best hope of identifying a route from the unity of consciousness to the experience of an objective world.

Paul Snowdon (2009, p. 450) has reported Strawson as saying that the favourite occupation of philosophers is stabbing their benefactors in the back. Since The Bounds of Sense counts as a benefit given to the philosophical community, this essay has continued that philosophical 
practice, not by damning with faint praise but by acclaiming with loud criticism. This shouldn't mask my love and admiration for Strawson's discussion, indeed for The Bounds of Sense as a whole. Strawson's arguments, like those of Kant before him, engage seriously and creatively with some of the deepest issues which arise when we think about ourselves as self-conscious subjects thrown into a world not of our making. ${ }^{12}$

12 This paper was presented at a workshop which marked the fiftieth-anniversary of the publication of The Bounds of Sense, held in Trinity College, Oxford, in May 2016. The other speakers were Ralph Walker, Paul Snowdon, and Mike Martin. Thanks to all those who took part for their comments and discussion. Particular thanks to Mike Martin, whose paper and comments were especially helpful in thinking about this topic. Versions of this material were also presented at the University of Nebraska-Lincoln, and Koç University. Thanks to Colin McLear and Harry Platanakis for the invitations and discussion. And thanks to Andrew Stephenson, Ian Phillips, Rory Madden, Nick Jones and Lee Walters for their comments and discussion. 


\section{References}

Beiser, F. C. (2002). German Idealism: The Struggle Against Subjectivism, 17811801. London: Harvard University Press.

Bennett, J. (1966). Kant's Analytic. Cambridge: Cambridge University Press.

Bennett, J. (1968). Strawson on Kant. Philosophical Review, 77(3), 340-349.

Burge, T. (2010). Origins of Objectivity. Oxford: Oxford University Press.

Campbell, J. (2002a). Berkeley's Puzzle. In T. S. Gendler \& J. Hawthorne (Eds.), Conceivability and Possibility. Oxford: Oxford University Press.

Campbell, J. (2002b). Reference and Consciousness. Oxford: Oxford University Press.

Cassam, Q. (1997). Self and world. Oxford: Oxford University Press.

Child, W. (1994). Causality, Interpretation, and the Mind. Oxford: Oxford University Press.

Evans, G. (1980). Things without the mind-A commentary on chapter two of Strawson's Individuals. In Z. Van Straaten (Ed.), Philosophical subjects. Oxford: Oxford University Press.

Gomes, A. (2011). Is There a Problem of Other Minds? Proceedings of the Aristotelian Society, 111(3), 353-373. doi: 10.1111/j.14679264.2011.00314.x

Gomes, A. (forthcoming). Naive Realism in Kantian Phrase. Mind.

Harrison, R. (1970). Strawson on outer objects. Philosophical Quarterly, 20(July), 213-221.

Harrison, R. (1974). On What There Must Be. Oxford: Clarendon Press.

Hurley, S. L. (1994). Unity and objectivity. In C. Peacocke (Ed.), Objectivity, Simulation, and the Unity of Consciousness (pp. 49-77). Oxford: Oxford University Press.

Hyman, J. (2003). Pains and Places. Philosophy, 78(303), 5-24.

Kalderon, M. E. (2007). Color pluralism. The Philosophical Review, 116(4), 563601.

Kant, I. (1992). Dohna-Wundlacken Logic. In Lectures on Logic, M.J. Young (ed./trans.), Cambridge: Cambridge University Press.

Kant, I. (1996). Groundwork of the Metaphysics of Morals. In Practical Philosophy, A.W. Wood (ed.), M.J. Gregor (trans.), Cambridge: Cambridge University Press.

Kant, I. (1998). Critique of Pure Reason, P. Guyer and A.W. Wood (eds./trans.), Cambridge: Cambridge University Press.

Kant, I. (2000). Critique of the Power of Judgment, P. Guyer (ed.), P. Guyer and E. Matthews (trans.), Cambridge : Cambridge University Press.

Kant, I. (2007). Anthropology from a Pragmatic Point of View. In Anthropology, History, and Education, R.B. Louden and G. Zöller (eds.), M.J. Gregor, P. 
Guyer, R.B. Louden, H. Wilson, A.W. Wood, G. Zöller, A. Zweig (trans.), Cambridge: Cambridge University Press.

Kant, I. (2012). Anthropology Mrongovius. In Lectures on Anthropology, A.W Wood and R.B Louden (eds.), R.R. Clewis, R.B. Louden, GF. Munzel, A.W. Wood (trans.), Cambridge: Cambridge University Press.

Kant, I. (1992). Dohna-Wundlacken Logic. In Lectures on Logic, M.J. Young (ed./trans.), Cambridge: Cambridge University Press.

Kant, I. (1996). Groundwork of the Metaphysics of Morals. In Practical Philosophy, A.W. Wood (ed.), M.J. Gregor (trans.), Cambridge: Cambridge University Press.

Kant, I. (1998). Critique of Pure Reason, P. Guyer and A.W. Wood (eds./trans.), Cambridge: Cambridge University Press.

Kant, I. (2000). Critique of the Power of Judgment, P. Guyer (ed.), P. Guyer and E. Matthews (trans.), Cambridge : Cambridge University Press.

Kant, I. (2007). Anthropology from a Pragmatic Point of View. In Anthropology, History, and Education, R.B. Louden and G. Zöller (eds.), M.J. Gregor, P. Guyer, R.B. Louden, H. Wilson, A.W. Wood, G. Zöller, A. Zweig (trans.), Cambridge: Cambridge University Press.

Kant, I. (2012). Anthropology Mrongovius. In Lectures on Anthropology, A.W Wood and R.B Louden (eds.), R.R. Clewis, R.B. Louden, G.F. Munzel, A.W. Wood (trans.), Cambridge: Cambridge University Press.

Moore, A. W. (2003). Noble in Reason, Infinite in Faculty: Themes and Variations in Kant's Moral and Religious Philosophy. London: Routledge.

Nudds, M. (2011). Children's understanding of perceptual appearances. In J. Roessler, H. Lerman \& N. Eilan (Eds.), Perception, Causation, and Objectivity. Oxford: Oxford University Press.

Peacocke, C. (2005). “Another I": Representing Conscious States, Perception, and Others. In J. L. Bermúdez (Ed.), Thought, Reference, and Experience: Themes from the Philosophy of Gareth Evans. Oxford: Oxford University Press.

Rorty, R. (1970). Strawson's Objectivity Argument. Review of Metaphysics, 24, 207-244.

Snowdon, P. (1980). Perception, Vision and Causation. Proceedings of the Aristotelian Society, 81, 175-192.

Snowdon, P. (1990). The Objects of Perceptual Experience. Proceedings of the Aristotelian Society, Supplementary Volumes, 64, 121-166.

Snowdon, P. (1998). Strawson on the Concept of Perception The Philosophy of P.F. Strawson. Chicago: Open Court.

Snowdon, P. (2009). 'Persons' and Persons. Organon F, 16(4), 449-476.

Snowdon, P. (2011). Perceptual Concepts as Non-causal Concepts. In J. Roessler, H. Lerman \& N. Eilan (Eds.), Perception, Causation, and Objectivity (pp. 121-138). Oxford: Oxford University Press. 
Soteriou, M. (2013). The Mind's Construction: The Ontology of Mind and Mental Action. Oxford: Oxford University Press.

Stevenson, L. (1982). Wittgenstein's Transcendental Deduction and Kant's Private Language Argument. Kant-Studien, 73(1-4), 321-337.

Strawson, P. F. (1954). Wittgenstein's 'Philosophical Investigations'. Mind, 63, 70-99.

Strawson, P. F. (1959). Individuals. London: Methuen \& Co. Ltd.

Strawson, P. F. (1966). The Bounds of Sense: An Essay on the Critique of Pure Reason. London: Methuen \& Co. Ltd.

Strawson, P. F. (1974a). Causation in Perception Freedom and Resentment and Other Essays. London: Methuen \& Co.

Strawson, P. F. (1974b). Wittgenstein's 'Philosophical Investigations' Freedom and Resentment and Other Essays. London: Methuen \& Co.

Strawson, P. F. (1979). Perception and its Objects. In G. F. Macdonald (Ed.), Perception and Identity: Essays Presented to A. J. Ayer. London: Macmillan.

Van Cleve, J. (1999). Problems from Kant. Oxford: Oxford University Press.

Walker, R. C. S. (1978). Kant. London: Routledge \& Kegan Paul.

Williams, B. (1978). Descartes: the project of pure enquiry. London: Penguin. 